\title{
A Case of Plasma Cell Mucositis Arising From the Larynx
}

\author{
Chang Bae Lee ${ }^{1}$ (D) Jae Won Heo ${ }^{1}$ (D) Min Gyoung Pak ${ }^{2}$ (D), and Dong Kun Lee ${ }^{1}$ (D) \\ Departments of ' $\mathrm{O}$ tolaryngology-Head and Neck Surgery and ${ }^{2}$ Pathology, College of Medicine, Dong-A University, Busan, Korea
}

후두에 발생한 형질 세포 점막염 1예

이창배 ${ }^{1}$, 허재원 ${ }^{1},{\text { 박민경 }{ }^{2}, \text { 이동근 }}^{1}$

동아대학교 의과대학 ${ }^{1}$ 이비인후-두경부외과학교실, ${ }^{2}$ 병리학교실

Plasma cell mucositis is a very rare benign disease characterized by dense lymphoplasmacytic infiltration in the submucosa layer. It appears as a reddish ulcer on the mucous membrane or as a cobblestone or nodular mass on the affected mucosa. When it involves the pharynx or larynx, the patient presents with dysphagia, voice change and dyspnea. Clinically, it is important to differentiate with malignant diseases such as extramedullary plasmacytoma, amyloidosis and sarcodosis. Several cases of mucositis in the larynx have been reported in English literature, but none have been reported in Korea. We report a case of plasma cell mucositis in the larynx with a review of literature.

Keywords Plasma cells; Larynx; Mucositis.

\section{서 론}

형질 세포 점막염(plasma cell mucositis)은 림프구와 형질 세포가 점막하층을 조밀 하게 침윤하여 발생하는 매우 드문 양성 질환 중의 하나로 인두나 후두에 발생할 경우 에 연하곤란, 발성장애, 호흡장애 등을 유발할 수 있다[1]. 해외에서는 구강부터 상기도 영역에서 발생한 경우가 약 28예였고, 성문상부의 병변은 11예가 보고되었다[2-4]. 국내 에서는 Heo 등[5]이 구인두 후벽에서 발생한 형질 세포증을 보고한 바 있으나, 후두에서 발생한 사례는 아직까지 발표된 적이 없다. 육안 소견상 점막의 발적 및 궤양소견으로 나타나기도 하며, 조약돌 모양이나 결절이 있는 종괴 소견으로 나타나기도 한다[2,3,6]. 적절한 치료를 위해서 골수외 형질 세포종(extramedullary plasmacytoma)과 편평세포 암(squamous cell carcinoma) 등의 악성 질환과 아밀로이드증(amyloidosis), 사코이드 증(sarcoidosis) 등의 양성 질환과도 감별이 필요하다[1,6,7]. 저자들은 목 불편감 및 목 소리 변화를 주소로 내원한 성인 남자 환자에게서 후두의 형질 세포 점막염을 진단하 고 이를 문헌 고찰과 함께 보고하는 바이다.

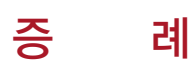

54세 남자 환자가 내원 10 일 전 목소리 변화 및 흡인 증상이 발생하여 내원하였다. 환

\author{
Received July 16, 2021 \\ Revised August 12, 2021 \\ Accepted August 13, 2021

\section{Corresponding Author \\ Dong Kun Lee, MD, PhD \\ Department of Otolaryngology- \\ Head and Neck Surgery, \\ College of Medicine, \\ Dong-A University, \\ 26 Daesingongwon-ro, Seo-gu, \\ Busan 49201, Korea \\ Tel +82-51-240-5428 \\ Fax +82-51-253-0712 \\ E-mail chaos001@hanmail.net}

\section{ORCID iDs}

Chang Bae Lee (D)

https://orcid.org/0000-0002-4741-0862 Jae Won Heo (D)

https://orcid.org/0000-0001-7715-556X

Min Gyoung Pak (D)

https://orcid.org/0000-0001-6142-4569

Dong Kun Lee (D)

https://orcid.org/0000-0002-7296-1420

This is an Open Access article distributed under the terms of the Creative

Commons Attribution Non-Commercial License (https://creativecommons.org/ licenses/by-nc/4.0) which permits unrestricted non-commercial use, distribution, and reproduction in any medium, provided the original work is properly cited. 
자의 기저질환으로 당뇨가 있었으며, 흡연력은 30갑년이나 5 년 전부터 금연한 상태였고, 술은 평소에 거의 마시지 않았 다. 후두 내시경 검사에서 우측 성대의 움직임이 부분적으로 감소된 소견이 관찰되어 원인 감별을 위하여 흥부 및 경부 컴 퓨터단층촬영 및 뇌자기공명영상 촬영을 시행하였으나 특이 소견은 없었고, 특발성 성대 마비로 진단 하에 prednisolone (Solondo 5 mg Tab ${ }^{\circledR}$; YuHan Corp., Seoul, Korea) 60 mg을 4일, 이후 하루 $10 \mathrm{mg}$ 씩 감량하여 5일 투여하였고, 약 한 달 뒤에는 성대 마비 및 목소리 변화 및 흡인 증상의 호전 소견 보였다. 약 1년 뒤 목 불편감 및 목소리 변화가 발생하여 외 래로 내원하였고 후두 내시경 검사에서는 양측 가성대(false vocal cord) 및 좌측 성문하부(subglottis)에 경계가 불분명 한 점막하(submucosal) 종괴가 관찰되었다(Fig. 1A).

경부 컴퓨터단층촬영 소견에서는 양측 전연합부의 병변에 서부터 시작되어 갑상연골 및 좌측 윤상연골을 침범한 후두 암이 의심되었고(Fig. 2A and B), 양측 경부 I, II 영역의 림프 절의 비대 소견으로 전이가 의심되었다(Fig. $2 \mathrm{C}$ and D). 전이 가 의심되는 림프절에 세침 생검을 시행하였으나, 병리 판독에 서 악성 소견은 없었다. 환자의 후두 병변 평가 및 생검을 위해
서 전신 마취 하에 후두미세현미경수술을 계획하였다. 수술 소견에서 좌측 성문하부에 전연합부는 침범하지 않는 종괴 소견과 양측 가성대의 점막하 종괴 소견이 있었고, 점막하 정 상 조직과 종괴의 경계가 구분되지 않았다. 수술 중 좌측 성문 하부 및 전연합부, 양측 가성대에서 부분적으로 검체를 채취 하여 시행한 동결절편검사를 시행하였다. 동결절편검사에서 는 염증성 병변으로 판단되며 암종일 가능성을 완전히 배제할 수는 없는데, 암종이라면 저등급의 림프종일 가능성이 높다 는 소견이었다. 림프종의 경우 항암치료가 주 치료이고, 염증의 경우에는 광범위한 절제보다는 전신적 약물 치료가 필요하기 때문에, 완전 절제보다는 조직학적 진단을 위한 부분 절제술 을 시행하였다(Fig. 1B). 이후 병리 조직검사에서는 점막하 염증 소견이 관찰되었고 뚜렷한 악성 종양의 소견은 없었다. 종괴를 형성하고 있는 염증은 대부분 형질 세포로 구성되어 있었고, 부분적으로 작은 림프구들이 섞여 있었다. 면역조직 화학염색에서 형질 세포 표지자인 CD138 (syndecan-1)에 광 범위하게 양성을 보였고, $\mathrm{B}$-림프구 표지자인 $\mathrm{CD} 20$ 에 부분적으 로 양성을 보였다. 작은 림프구들은 $\mathrm{T}$-세포 표지자인 $\mathrm{CD} 45 \mathrm{RO}$ 에 양성을 보였다(Fig. 3). 비정상적인 혈관 증식이나 비정형
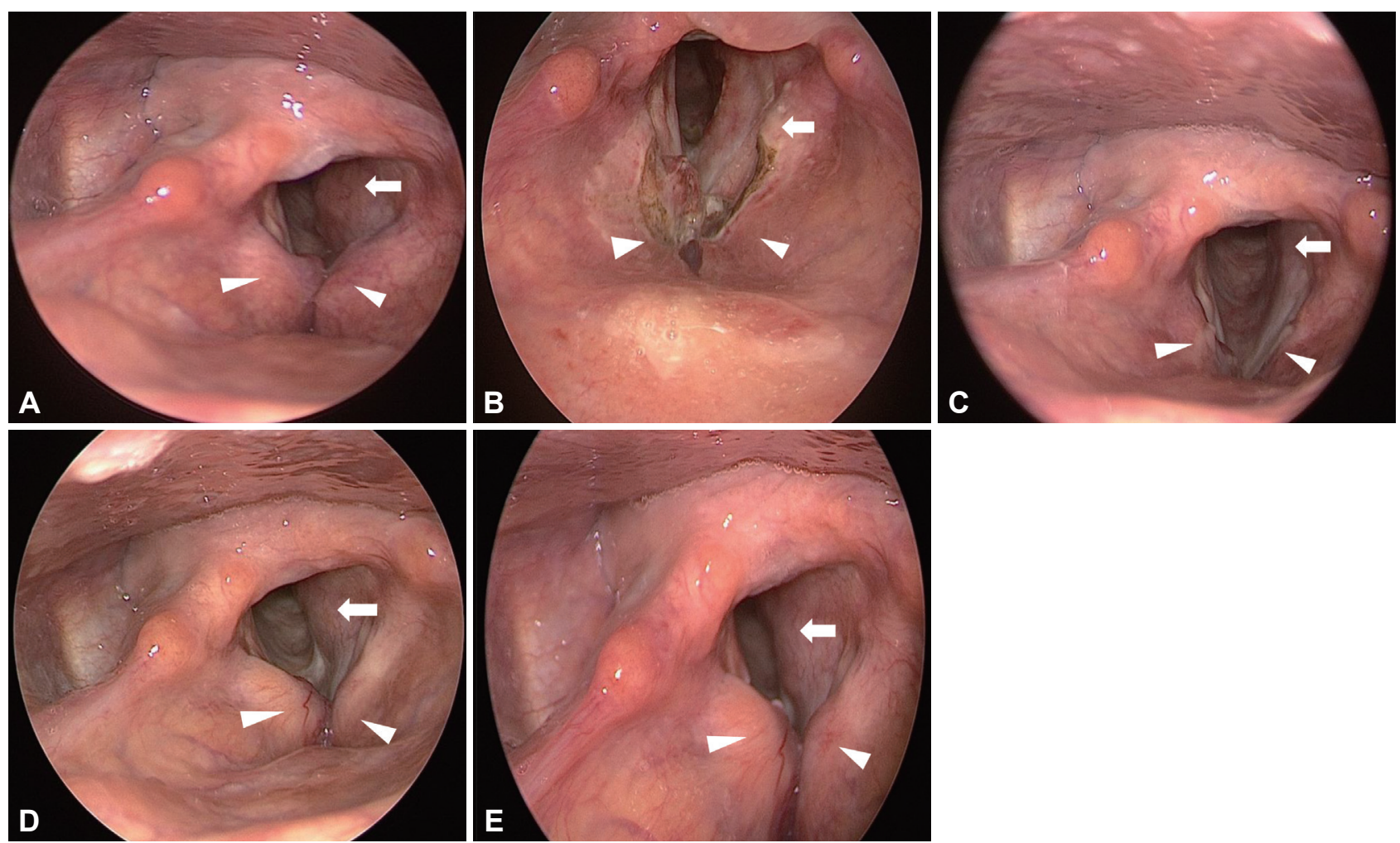

Fig. 1. Laryngoscopic findings. A: The ligid laryngoscopy finding before the surgery. It shows submucosal masses in both false vocal cord (arrowheads) and subglottis (arrow). B: The ligid laryngoscopy finding 1 week after the surgery. It shows partially resected mass in the both false vocal cord (arrowheads) and subglottic mass (arrow). C: The ligid laryngoscopy finding 1 month after the surgery. It shows diffuse focal remnant mass on the false vocal cord (arrowheads) and subglottis (arrow). D: The ligid laryngoscopy finding 11 months after surgery. It shows diffuse focal remnant mass on the false vocal cord (arrowheads) and subglottis (arrow). E: The ligid laryngoscopy finding 19 months after surgery. It shows slightly increased masses on the both vocal cord (arrowheads) and left subglottis (arrow). 

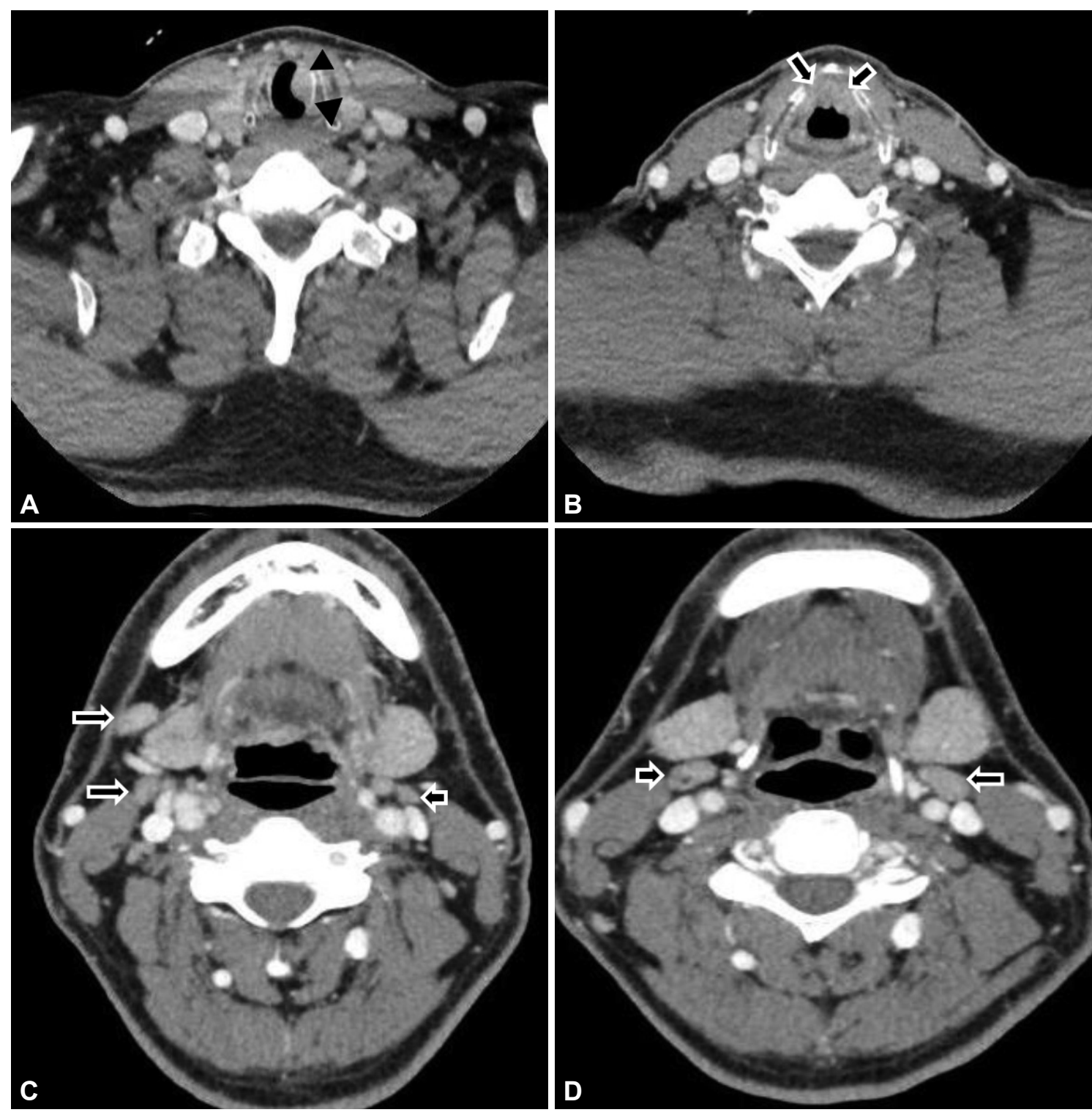

Fig. 2. Axial neck CT findings. A: Axial scans of computed tomography shows hypodense laryngeal mass involving the left subglottis (arrowheads). B: Both supraglottis (arrows). C and D: Axial scans of computed tomography shows multiple small lymph nodes in neck level I and II areas (arrows).

림프구가 관찰되지 않고, NK cell 표지자인 CD56에도 음성 을 보여 extranodal NK/T-cell lymphoma는 배제할 수 있 었다. 또한 혈액종양내과에 B세포 기원의 림프종 또는 형질 세 포 질환(plasma cell disorder)의 감별을 위해서 협진을 의뢰 하였다. 무작위 소변 단백뇨(random urine protein) 검사는 $14 \mathrm{mg} / \mathrm{dL}$ (정상치 0-20), free $\kappa$ light chain (S)는 $27.61 \mathrm{mg} / \mathrm{L}$ (3.30-19.40), free $\lambda$ light chain (S)는 $21.56 \mathrm{mg} / \mathrm{L}$ (5.71-26.30) 로 다발성 골수종을 의심할 만한 소견은 없었다. 혈청 및 소변 면역고정전기영동(serum and urine immunofixation electrophoreses) 및 면역글로불린 G 아형 검사에서도 특이 소견 없 었다. 형질 세포 점막염과 골수외 형질 세포종을 감별하기 위
해서 병리과 자문 및 환자 동의 하에 immunoglobulin heavy chain gene rearrangement를 추가로 시행하였으며, 검사 결 과는 음성으로 종양 소견이 아니고 염증이라는 것이 입증되 어 악성 종양인 형질 세포종을 배제할 수 있었다. 환자는 최 종적으로 형질 세포 점막염으로 진단하여 주기적으로 종괴의 크기 및 상태를 경과 관찰하기로 하였다.

수술 한 달 후, 후두 내시경에서 양측 가성대와 성문하 병변 의 잔여 종괴는 남아 있었으나 크기 변화는 없었다(Fig. 1C). 추적 관찰을 위해 시행한 경부 컴퓨터단층촬영 및 흥부 컴 퓨터단층촬영에서도 진행된 병변이나 특이 소견은 없었다. 환자는 수술 후 한 달마다 외래에서 진료를 시행하였으며, 후 

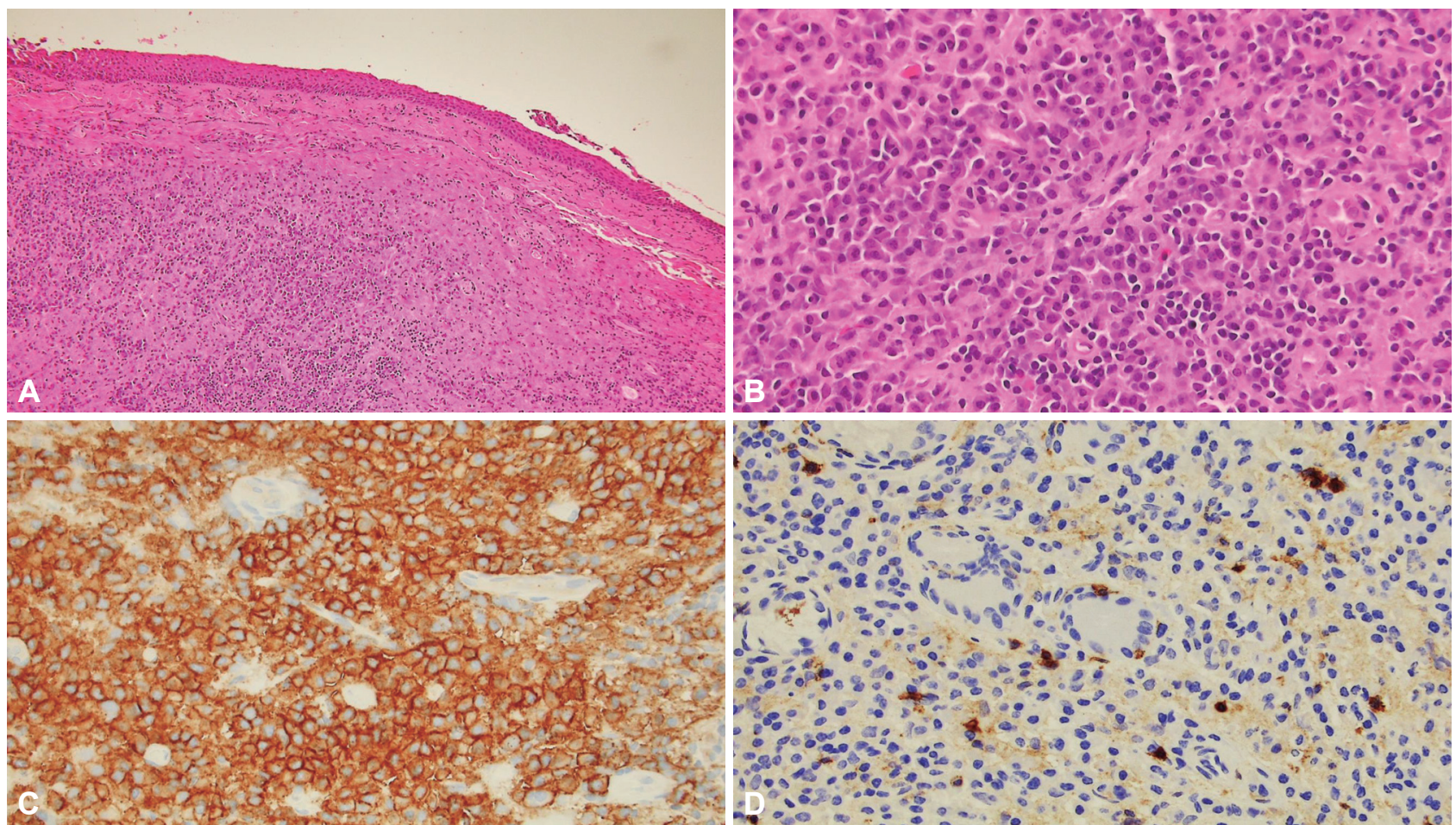

Fig. 3. Histopathologic findings. A: Dense inflammatory cell infiltration is observed at the submucosal connective tissue. No mucosal ulceration or vascular proliferation is noted (hematoxylin and eosin [HE] staining, $\times 100$ magnification). $B$ : There are numerous plasma cells with abundant basophilic cytoplasm and eccentric nucleus (HE staining, $\times 400$ magnification). C: CD138 (syndecan-1) reactivity was observed for nonneoplastic plasma cells (CD138, ×400 magnification). D: Some scattered small lymphocytes show positive immunoreactivity for pan T-cell marker; CD45RO (CD45RO, ×400 magnification).

두의 종괴는 조금씩 증가하는 소견을 보였다.

수술 후 10개월째부터 prednisolone을 $40 \mathrm{mg} /$ 일 3주, 30 $\mathrm{mg} /$ 일 5 주, $20 \mathrm{mg} /$ 일 2주, $10 \mathrm{mg} /$ 일 3주, $5 \mathrm{mg}$ /일 3주로 감 량하면서 후두 내시경 검사를 통해 크기 변화를 한 달에 한 번씩 추적 관찰하기로 하였다. 스테로이드 치료 1개월째, 종 괴의 크기는 다소 감소하는 추세였고, 목소리 변화는 이전보 다 호전되는 양상이었다(Fig. 1D).

환자는 스테로이드를 복용하는 동안 혈당이 233-564 mg/dL 으로 증가하였고, 당뇨 약 조절과 혈당 관리 교육을 시행하였 다. 스테로이드 치료는 3 개월 동안 사용 후에 종결하였으며, 주 기적으로 2 개월마다 관찰하였다. 종괴의 크기는 스테로이드 를 쓰면 천천히 감소하고, 약을 끊으면 천천히 증가하는 양상 이었다. 스테로이드 치료 종결 9개월째 종괴의 크기가 서서히 증가하여 다시 류마티스내과 협진으로 Solondo보다는 혈당 상승 작용이 적은 deflazacort $18 \mathrm{mg}$ (Calcort Tab ${ }^{\circledR}$, Handok Pharmaceutical Co., Ltd., Seoul, Korea)을 2달여간 복용하 였다(Fig. 1E). 종괴의 크기는 다시 조금씩 작아지는 양상이 며, 지속적으로 본과 외래에서 종괴의 양상을 주기적으로 추 적 관찰 중이다.

\section{고 찰}

형질 세포 점막염은 림프구와 형질 세포가 점막하층을 조밀 하게 침윤하여 발생하는 드문 비종양성 질환 중의 하나로, 입 술, 잇몸, 혀, 협부, 후두, 후두개, 성기 등의 점막 부위에서 주 로 발병하며 코점막, 하기도 등에서도 발생한다[1,3,8]. 발병 부위 따라서 치은구내염(ginivostomatitis), 구인두점막 형질 세포 증가증(oropharyngeal mucosal plasmacytosis), 형질 세포 치은염(plasma cell gingivitis), 점막세포형질구증가증 (mucous membrane plasmacytosis) 등으로 명명된다[9-11]. 1952년 Zoon[12]이 조밀한 형질 세포가 귀두의 점막에 침윤 해 있는 것을 관찰하여 처음으로 보고하였다. Ferreiro 등[4] 은 상기도에 국한된 형질 세포 점막염을 8예 보고하였다. 국 내문헌에서는 $\mathrm{HeO}$ 등[5]이 구인두 후벽에 발생한 점막 형질 세포증으로 절제술을 시행한 사례를 1예 보고한 바 있으나, 후두에 국한되어 발생한 사례는 아직까지 국내에는 보고된 바가 없다.

임상증상으로는 염증 부위의 통증이 발생할 수 있으며, 인 두나 후두에 발생 시 연하곤란, 발성장애, 호흡장애 등을 동 반할 수 있다[3]. 형질 세포 점막염의 정확한 기전이나 원인은 
아직 밝혀지지 않았으나, Solomon 등[2]은 기저질환에 자가 면역 질환이 있는 경우 발병률이 높다고 하였으며, Lee 등[13] 은 전신홍반루푸스, 쇼그렌 증후군 같은 질환에서 동반되기 도 한다고 보고하였다. 치약이나 츄잉검(chewing gum)의 성 분 또는 외부 물질에 의한 알레르기 반응도 원인이 될 수 있다 는 보고도 있다[8].

병리조직 소견상 다수의 성숙한 형질 세포로 구성된 염증 세포의 침윤이 점막하층을 침범하는 형태가 특징적으로 나 타나며 일부 다핵형 백혈구나 림프구가 동반되어 있기도 하 다[14]. 이는 아밀로이드증이나 사르코이드증, 형질 세포종과 유사하기도 하여 감별이 필요하다. 침윤된 형질 세포의 세포 질 내에는 때때로 면역글로불린이 축척되어 나타나는 소견인 Russell body가 관찰되기도 한다. 면역조직화학염색 시에는 $\kappa, \lambda$ light chain과 여러 종류의 heavy chain이 혼합된 다클 론형이 나타난다[4]. Aiba와 Tagami[15]는 $\operatorname{IgG}$ 와 $\operatorname{IgA}$ 및 kappa chains의 생성이 lambda chain보다 우세하게 나타난 다고 보고하였다.

형질 세포 점막염의 가장 흔한 치료는 경구 스테로이드이다 [16]. 복용 이후에 증상의 호전을 보이는 경우가 있으나, 효과 적인 치료가 되지 않았다는 보고도 있다[17]. 구강에서 후두 영역까지 발생한 형질 세포 점막염을 조사하였을 때 국외 보 고 28예 중 후두에서 발생한 경우는 14예이다. 14예 중에서 스테로이드 치료를 8 예에서 시행하였으며, 그중 5 예에서 병변 의 호전 소견을 보였다. 후두 외 부위에서 발생한 경우는 14예 이며, 스테로이드는 9예에서 사용하였고, 그중에 6예의 환자 에서 호전 소견을 보였다[2-4].

본 증례의 환자도 수술 후에 스테로이드를 복용함으로써 재발하는 종양의 크기를 다소 줄이고 증상을 완화시킬 수 있 었으나 크기 감소가 느렸고 종괴를 확연히 줄일 수는 없었다. 전신적으로 스테로이드를 $50 \mathrm{mg}$ /일 정주하는 것이 증상을 줄 이는데 도움이 되며, 추가로 혈소판풍부피브린(platelet rich fibrin) 주사를 같이 병변에 시행하는 것이 병변의 염증 침윤 을 줄이는 데 도움이 되었다는 보고도 있다[18]. 또한 베타메 타손(betamethasone) 가글과 크림이 구강 병변을 치료하는 데 도움이 되며 피하에는 종양괴사인자 억제제(tumor necrosis factor inhibitor)인 아달리무맙(adalimumab) 크림을 사용하는 것이 증상 완화에 도움이 된다는 보고가 있다 [19]. 당뇨나 간염과 같은 기저질환이 있는 형질 세포 점막염 환자에서는 상대적으로 스테로이드 치료를 하기 어려운 면이 있다. 본 증례에서도 prednisolone을 복용한 후 환자의 혈당 이 233-564 mg/dL으로 증가하여 조절이 힘든 면이 있어서 이후, 인슐린 내성이 상대적으로 작은 prednisolone 유도체인 deflazacort를 사용하였고 이후에는 혈당이 150-230 mg/dL
대로 이전보다 양호하게 조절되었다. 기저질환이 없는 환자는 prednisolone을 먼저 복용해볼 수 있겠지만, 상대적으로 스 테로이드 치료 금기증이 있는 환자군에서는 수술적 치료와 함께 prednisolone 유도체를 사용하는 방법도 고려해볼 수 있을 것이다.

수술적 치료로는 단순 절제나 $\mathrm{CO}_{2}$ 레이저를 이용한 절제 를 시행하는 경우가 있다[1,20]. 그러나 단순 절제는 증상의 개 선을 가져올지라도 병의 진행을 막지는 못하며, 방사선 치료를 시행하는 것이 병변에 도움이 되었다는 보고도 있다[4].

기도의 병변으로 인한 성문상부의 협착 또는 기도 협착증 의 합병증이 있는 경우 기도 확보를 위해서 풍선확장술을 시 행하거나[21] 기관지 절제술을 시행한 사례가 있었다[15]. 다 른 치료로는 병변에 $0.03 \%$ 타크로리무스(tacrolimus) 또는 사이크로스포린(cyclosporine)을 국소 도포를 시행하거나 [17,22], 냉동치료(cryotherapy)를 시행할 수 있다[23]. 면역억 제제인 마이코페놀릭산(mycophenolic acid), 클로람부실 (chlorambucil), 메토트렉세이트(methotrexate) 등을 쓰는 것이 장기간 재발 방지에 효과가 있다는 보고도 있다[16,24,25]. 본 증례에서는 아직 스테로이드 치료에 반응이 있어 스테로 이드 치료를 지속할 계획이다. 하지만 환자의 기왕력으로 당 뇨가 있어 향후 지속적으로 혈당 조절이 되지 않는다면 앞의 면역억제제 치료도 고려하고 있다. 스테로이드 치료에 반응이 없거나 스테로이드를 지속적으로 사용할 수 없는 환자에서 면역억제제 치료도 고려해볼 수 있다.

형질 세포 점막염이 의심되는 환자가 내원 시에는 아직까지 정립된 치료 방법은 없으나, 악성질환 및 다른 질환을 배제하 기 위해서 적극적인 검사 및 진단을 시행하고 환자의 다양한 증상 및 병변의 위치에 맞는 약물 치료나 수술적 치료 계획을 수립하는 것이 필요하다. 형질 세포 점막염이 편평세포암으로 진행되었다는 보고도 있어서 치료 후에도 정기적인 관찰이 필요하다[16].

중심 단어: 형질 세포; 후두; 점막염.

Acknowledgments

None.

Conflicts of Interest

The authors have no financial conflicts of interest.

Authors' Contribution

Conceptualization: all authors. Data curation: Jae Won Heo. Investigation: Chang Bae Lee. Resources: Min Gyoung Pak. Supervision: Dong Kun Lee. Writing_original draft: Chang Bae Lee. Writing_review \& editing: Dong Kun Lee.

\section{REFERENCES}

1. White JW Jr, Olsen KD, Banks PM. Plasma cell orificial mucositis. 
Report of a case and review of the literature. Arch Dermatol 1986; 122(11):1321-4.

2. Solomon LW, Wein RO, Rosenwald I, Laver N. Plasma cell mucositis of the oral cavity: Report of a case and review of the literature. Oral Surg Oral Med Oral Pathol Oral Radiol Endod 2008;106(6):853-60.

3. Khan NA, McKerrow WS, Palmer TJ. Mucous membrane plasmacytosis of the upper aerodigestive tract. A case report with effective treatment. J Laryngol Otol 1997;111(3):293-5.

4. Ferreiro JA, Egorshin EV, Olsen KD, Banks PM, Weiland LH. Mucous membrane plasmacytosis of the upper aerodigestive tract. A clinicopathologic study. Am J Surg Pathol 1994;18(10):1048-53.

5. Heo KW, Chang HJ, Lee SR, Kwon CH. A case of mucous membrane plasmacytosis arising from oropharynx. Korean J OtorhinolaryngolHead Neck Surg 2005;48(12):1544-7.

6. Puvanendran M, Lieder A, Issing W. Plasma cell mucositis of oroand hypopharynx: A case report. Case Rep Otolaryngol 2012;2012: 304136.

7. Madhavarajan S, Tighe J. Orofacial plasmacytosis: A management conundrum. Br J Oral Maxillofac Surg 2015;53(4):399-402.

8. Perry HO, Deffner NF, Sheridan PJ. Atypical gingivostomatitis. Nineteen cases. Arch Dermatol 1973;107(6):872-8.

9. Tong DC, Leaper MR, Colquhoun AN, Rich AM. An unusual presentation of oropharyngeal mucosal plasmacytosis related to toothpaste. J Laryngol Otol 2008;122(10):1112-4.

10. Sollecito TP, Greenberg MS. Plasma cell gingivitis. Report of two cases. Oral Surg Oral Med Oral Pathol 1992;73(6):690-3.

11. Lucarelli MR, Allen JN, Magro CM. Plasma cell mucositis of the distal airways. Thorax 2005;60(2):173.

12. Zoon JJ. Chronic benign circumscript plasmocytic balanoposthitis. Dermatologica 1952;105(1):1-7.

13. Lee LA, Fang TJ, Li HY. Solitary plasmacytosis of the larynx in a patient with non-Hodgkin's lymphoma. Am J Otolaryngol 2002;23(5): 316-20.

14. Bharti R, Smith DR. Mucous membrane plasmacytosis: A case report and review of the literature. Dermatol Online J 2003;9(5):15.
15. Aiba S, Tagami H. Immunoglobulin-producing cells in plasma cell orificial mucositis. J Cutan Pathol 1989;16(4):207-10.

16. Pepper T, Shekar K, Singh M, Brennan PA. Squamous cell carcinoma arising in mucosal plasmacytosis. Br J Oral Maxillofac Surg 2010; 48(3):208-10

17. Jin SP, Cho KH, Huh CH. Plasma cell cheilitis, successfully treated with topical $0.03 \%$ tacrolimus ointment. J Dermatolog Treat 2010; 21(3):130-2.

18. Gasparro R, Adamo D, Masucci M, Sammartino G, Mignogna MD. Use of injectable platelet-rich fibrin in the treatment of plasma cell mucositis of the oral cavity refractory to corticosteroid therapy: A case report. Dermatol Ther 2019;32(5):e13062.

19. Galvin S, Bowe C, O Regan EM, Conlon N, Flint SR, Healy CM. Circumorificial plasmacytosis/plasma cell orificial mucositis: A case series and a review of the literature. Oral Surg Oral Med Oral Pathol Oral Radiol 2016;122(3):e77-81.

20. Fogarty G, Turner H, Corry J. Plasma cell infiltration of the upper aerodigestive tract treated with radiation therapy. J Laryngol Otol 2001;115(11):928-30.

21. Mistry SG, Watson GJ, Rothera MP. Balloon dilatation to treat plasmacytosis of the supraglottic larynx. J Laryngol Otol 2012;126(10): 1077-80.

22. Heinemann C, Fischer T, Barta U, Michaelides A, Elsner P. Plasma cell mucositis with oral and genital involvement - successful treatment with topical cyclosporin. J Eur Acad Dermatol Venereol 2006; 20(6):739-40

23. Najarian DJ, Rao BK, Pappert AS. A case of mucous membrane plasmacytosis successfully treated with cryotherapy. Dermatol Online J 2008;14(2):6.

24. Gupta SR, Gupta R, Saran RK, Krishnan S. Plasma cell mucositis with gingival enlargement and severe periodontitis. J Indian Soc Periodontol 2014;18(3):379-84

25. Triplett J, Hee G, McLean-Tooke A, Lucas M. Long-term control of laryngeal plasma cell mucositis with systemic immunosuppression. BMJ Case Rep 2018;2018:bcr2017221333. 